\title{
TRACING THE ORIGINS OF EARLY SYMPHONIC REPERTOIRE IN THE SLOVENIAN LANDS
}

\author{
VESNA VENIŠNIK \\ Filozofska fakulteta Univerze v Ljubljani
}

\begin{abstract}
Izvleček: V 18. stoletju je simfonični repertoar $v$ slovenskih deželah obsegal dela znanih skladateljev, ki so bila razširjena po celotni Evropi. Medtem ko so avtorji najzgodnejših primerov simfoničnega žanra, ki datirajo že v trideseta leta 18. stoletja, delovali na različnih koncih Evrope, so bile simfonije ob koncu stoletja skoraj izključno delo skladateljev, delujočih v Habsburški monarhiji.
\end{abstract}

Ključne besede: simfonični repertoar, prenos del, prepisi in tiski, 18. stoletje, Habsburška monarhija, Slovenija.

\begin{abstract}
In the eighteenth century the symphonic repertoire in the Slovenian Lands consisted mainly of works that were performed throughout Europe and were written by famous composers. While the composers of the earliest examples of the genre, dating from as late as the 1730s, lived in various nations, at the end of the eighteenth century the symphonic repertoire consisted almost exclusively of works by composers working in the Habsburg monarchy.
\end{abstract}

Keywords: symphonic repertoire, transmission, manuscript and prints, eighteenth century, Habsburg monarchy, Slovenia.

The extant manuscripts and prints of early symphonic music preserved in various archives throughout Slovenia and in the border town of Gorizia confirm that during the eighteenth century this territory followed broader European symphonic currents and was acquainted with contemporary examples of the genre. The increased symphonic production throughout the century was probably due to the fact that the symphony was very versatile in its functions and integrated into different social environments. This was true also of the Slovenian Lands. The present article traces three different types of patronage of the symphonic repertoire that were characteristic of the Slovenian Lands in the eighteenth century. Proceeding chronologically, it first examines the earliest examples of symphonies dating from the 1730 s to the 1760 s, which were owned by aristocratic Gorizian families and are today held by the Historical Archive of Gorizia (Archivio storico provinciale di Gorizia). The focus then shifts to the repertoire found in religious institutions from the 1750s until around 1780; finally, there is a comparison of the repertoire of the Philharmonic Society, founded in 1794 in Ljubljana, with the symphonies preserved in the Historical Archive of Gorizia that date from the end of the century. 
Throughout the eighteenth century the symphonic repertoire of the Slovenian territory was significantly influenced by the preferences of the wider region to which it belonged politically. In order to understand this connection a brief account of this historical-geographic background must be provided. In the eighteenth century the modern-day Slovenian territory was governed by three powerful countries. The majority of the territory belonged to the Habsburg Empire in the shape of the Inner-Austrian hereditary lands: the Duchies of Carinthia and Carniola and the Archduchy of Styria, plus the County of Gorizia and Gradisca and the city of Trieste. The coastal areas, including the towns of Koper (It. Capodistria), Izola (Isola) and Piran (Pirano), the Alpine valleys of Rezija (Resia) and the river basin of Nadiža (Natisone) and Tera (Pradielis), belonged to the Venetian Republic (until 1797), while Prekmurje and Porabje in the far north-eastern corner of present-day Slovenia formed part of the Kingdom of Hungary. The characteristics of the symphonies preserved in Slovenian collections are comparable to those of other collections in the Habsburg monarchy, although the County of Gorizia's border with the Venetian Republic seems to have influenced the repertoire there.

Sadly, very few musical collections once belonging to the local nobility are preserved. The largest collection is preserved in the Historical Archive of Gorizia, ${ }^{1}$ while the only other musical collection from this early period containing symphonic works originates from Slovenska Bistrica and was previously owned by Count Ignaz von Attems and his wife Josepha. $^{2}$ The second collection contains the sinfonia from Johann Adolph Hasse's opera Asteria from 1737. ${ }^{3}$ The County of Gorizia was populated by many aristocratic families, who, judging by the preserved instrumental music held by the Historical Archive of Gorizia, were very fond of music. ${ }^{4}$ The extant works include numerous symphonic compositions, which reflect an almost continuous cultivation of symphonic music throughout the century.

The symphonies from the period between the 1730s and 1760s are the earliest examples of the symphonic genre preserved in this territory, and are mainly works by the pioneers of the genre. ${ }^{5}$ The Italian contribution is represented by the so-called Milan school. We can find one symphony by Antonio Brioschi, while among certain anonymous works the present author recently discovered three symphonies by Giovanni Battista Sammartini. There are also operatic sinfonias by other Italian composers who were either contemporaries of Sammartini (Antonio Vivaldi, Domenico Francesco Negri, Giorgio Giulini, Baldassare Galuppi) or belonged to an even earlier generation. The Gorizian collection also includes examples of the genre by the Mannheim composers Ignaz Holzbauer, Johann

1 A complete catalogue of the musical collection preserved in the Historical Archive in Gorizia has been compiled by Alessandro Arbo; see Arbo, I fondi musicali. On musical life in Gorizia, see Arbo, Musicisti di frontiera; on symphonic music from this collection, see Venišnik, "Simfonični repertoar Goriške dežele."

2 Kokole, "Glasba v plemiških bivališčih," 686. For more information on Ignaz von Attems, see Kokole, "Glasbeni utrinki," 58-61, with references.

3 Title on source: “Ouverture Con Wr e Viola| Del Sig:| Giou: Adolfo Hasse.” Maribor, Pokrajinski arhiv (SI-Mpa), 1857/010/00093.

4 Kokole, "Glasba v plemiških bivališčih," 689.

5 Information on composers and the symphonic repertoire in general given in this article is generally based on that in Morrow and Churgin, Eighteenth-Century Symphony. 
Stamitz and Carl Joseph Toeschi, as well as one symphony by Johann Christian Bach dating from his early symphonic period and one symphony by Johann Gabriel Seyffarth of the Berlin court. From the composers of the Habsburg empire, the only symphonies represented are by Georg Christoph Wagenseil - which is not so unexpected, since he was the only Austrian symphonist of his generation to achieve an international reputation.

The majority of these symphonies, all of which are manuscript copies, are found in several volumes that include quartets, trios, sinfonia, divertimentos and sonatas - compositions that were later bound together. This has sadly given rise to a number of anonymous works that exhibit the standard form of the early symphonies. These symphonies mainly belong to the early decades of the symphony (including in this definition operatic sinfonias), featuring three movements scored, with only a few exceptions, for an orchestra consisting solely of strings.

The symphonic repertoire of this period had an international orientation, which was also characteristic of other European collections; the works of these composers were in general very well known and disseminated throughout Europe. ${ }^{6}$ Specific information on how these works were acquired is lacking. It is likely that the anonymous works are principally of Italian origin, since the other chamber works contained in the volumes just mentioned are by Italian composers. That fact suggests that this repertoire was drawn from what was available in Italy, especially Venice.

There is, however, one characteristic of the Gorizian repertoire that is quite distinctive. The symphonies mainly originate from the early or middle compositional periods of their respective composers; there are no examples of their mature works exhibiting a four-movement structure and other advanced characteristics. Moreover, there is a gap in the repertoire, since an entire generation of composers is completely absent. There are no works by Johann Baptist Wanhal (Vaňhal) or Carl Ditters von Dittersdorf, for instance; nor are there any symphonic works by Luigi Boccherini, despite the presence of his quartets in the volumes. (The single preserved Haydn symphony was written in 1782 and his Sinfonia concertante in 1792.) The sole exception to this apparent dearth is a symphony attributed to Leopold Mozart that is not listed in his thematic catalogue. The presence in one of the volumes of an Andante from Ignaz Pleyel's Symphonie Concertante in E flat major suggests that, rather than being lost, symphonies dating from the late 1760s to the 1770 s were in fact never acquired.

Among the important patrons of the symphonic repertoire in the eighteenth century were religious institutions, where symphonies were used for liturgical and devotional purposes as well as during festivities. ${ }^{7}$ Numerous monastery collections contain vast numbers of symphonies attesting to the Church's prominent role in the cultivation of the genre. Monasteries are considered to have been significant patrons of the symphony, especially in the Habsburg monarchy, ${ }^{8}$ and some examples of the genre can be found also in Slovenian religious institutions, albeit in small quantities.

6 Morrow, "Patrons and Practices," 81-82.

7 Riedel, "Joseph Haydns Sinfonien," 214. On the use of symphonies during the liturgy, see Zaslaw, "Mozart, Haydn;" Riedel, "Die Bedeutung," 6, and Beck, "Die Musik," 189.

8 Morrow, "Patrons and Practices," 77. 
The Franciscan monastery in Novo mesto holds several symphonic works including two printed collections, one of symphonies and one of operatic sinfonie. ${ }^{9}$ All of these works are oriented towards the local Austrian production, and some are by the most popular composers of the era. They include a Symphony in A major (A4) ${ }^{10}$ by Dittersdorf and a Symphony in $\mathrm{C}$ major $(\mathrm{C} 1)^{11}$ by Wanhal, as well as the popular edition of Sei sinfonie a grande orchestra ${ }^{12}$ (a collection of six operatic sinfonias) by Joseph Haydn. The works of Haydn, Dittersdorf and Wanhal were widely distributed, as was the overture to the very successful opera La buona figliuola by Niccolò Piccinni. ${ }^{13}$ Conversely, L. Mozart's works were not so well known, being largely confined to Habsburg territory. Mozart's Symphony in $\mathrm{G}$ major $(\mathrm{G} 3)^{14}$ undoubtedly came to this monastery by virtue of its clear religious connection: this symphony is actually an instrumental pastorella intended specifically for church performance. The symphonies that do not originate from Austrian territory demonstrate the fact that the monasteries themselves formed an autonomous channel of transmission. This was very likely a result of the constant relocation of monastery residents, which is a likely explanation for how a symphony by the Czech composer Antonín Kammel found its way there. This work was probably brought to Slovenian territory by that composer's compatriot, the Franciscan friar Mauritius Pöhm, when he settled in Novo mesto in the 1770 s. ${ }^{15}$ The fact that monasteries shared a cultural connection emerges similarly from a printed collection of twelve symphonies by F. Kraus Lambert from the Bavarian monastery at Metten, which survives almost exclusively in monastic archives. Typically, the works of monastic composers are concentrated in monastery collections. ${ }^{16}$

The monastery of St Francis in Piran holds the sinfonia to the opera Solimano by Johann Gottlieb Naumann, ${ }^{17}$ while in the archive of Koper Cathedral we find a threemovement work that could be either a chamber symphony or an operatic sinfonia and

9 For information on the musical collection of the Franciscan monastery in Novo mesto, see: on church music, Škrjanc, "Prispevek k poznavanju repertoarja;" on choirbooks, Škrjanc, "Frančiškanske korne knjige v Novem mestu iz 18. stoletja;" on the "Fundamenta" textbook, Škrjanc, "Relativnost in funkcija," and Škrjanc, "O času in kraju nastanka;" on musical works from the eighteenth and nineteenth centuries, Höfler, "Glasbenozgodovinske najdbe;" Bizjak "Frančiškani in glasba v 18. stoletju;" Faganel, "Glasba klasicizma;" Faganel, "Glasbeni repertoar;" on the symphonic repertoire, Venišnik, "Instrumental Music and Franciscan Liturgy." The complete collection of the Franciscan monastery in Novo mesto has been catalogued and included in the RISM A/II database (SI-Nf).

${ }^{10}$ Title on the source: "Sinfonia Ex A | a | Violino Primo | Violino Secundo | Alto. Viola | è | Basso | Authore Sigr. Carolo Titters." SI-Nf, Ms. mus. 277.

${ }^{11}$ Untitled. SI-Nf, Ms. mus. 504.

12 RISM H 3288; HH 3288; SI-Nf, 343.

${ }^{13}$ Title on the source: "Sinfonia in D. | a | Due Violini | Due Oboe | Due Corni | Viola | e Basso | Del Sig: Niccolo Piccinni." SI-Nf, Ms. mus. 284. On Piccinni's operatic sinfonia to La buona figliuola, see Kokole, "1773 Production of Piccinni’s La buona figliuola."

${ }^{14}$ Diplomatic title: "Pastorelle ex G | a | Violino Primo | Violino Secundo | Viola obl. | Cornu Pastoris ex G $\mid$ con | Basso | Del Sig. Mozart.” SI-Nf, ms. mus. 282.

${ }^{15}$ Faganel, "Glasba klasicizma v novomeških arhivih," 215.

${ }^{16}$ Morrow, "Symphony in the Austrian Monarchy," 422.

17 Title on source: "Sinfonia del Sig ${ }^{\mathrm{r}}$ Amadeo Naumann." SI-Plm, Ms. mus. B-27. 
was most likely written by Giacomo Rampini, an Italian composer and organist who worked as an organist at the cathedral of Udine from 1775 onwards. ${ }^{18} \mathrm{~A}$ shift towards local production can likewise be observed in the remainder of the repertoire of this cathedral at the end of the eighteenth century, since works were by then obtained no longer from Venice but rather from musicians living in nearby cities such as Trieste and the towns of the Friuli area in the north-east of Italy. ${ }^{19}$

Interestingly enough, the preserved works of the Cathedral of Ljubljana show a preference for the French repertory. A printed collection of three symphonies by Simon Leduc, Carl Stamitz and François-Joseph Gossec used to belong to the cathedral, as did a printed edition of the Symphony in D major, op. 5, no. 1, by Giuseppe Maria Cambini, an Italian composer who worked in France (Leduc le Jeune, Paris). ${ }^{20}$ Gossec's and C. Stamitz's symphonies were also present in other Habsburg collections, whereas Cambini was better known for his quartets and sinfonie concertanti than for his ordinary symphonies. Only rare examples of French symphonies entered the Austrian repertoire, and this situation is reflected also in Slovenian archives. Haydn's Symphony No. 35 in B flat major was also owned by the cathedral. ${ }^{21}$

The works of this type in these religious establishments were acquired between the 1750s and the 1780s, the period when Austrian monasteries also obtained most of their symphonic repertoire. ${ }^{22}$ The Josephine reforms of the 1780 s not only closed several monasteries but also curtailed the musical accompaniment to the liturgy, thereby automatically reducing the Church's demand for symphonies.

By the end of the century the symphonic repertoire in the Habsburg monarchy had become oriented almost exclusively towards local production. ${ }^{23}$ This is characteristic of the Gorizian region and of the repertoire of the Philharmonic Society (Philharmonische Gesellschaft) in Ljubljana, founded in 1794. In the Gorizian collection works by popular composers such as Adalbert Gyrowetz and Ignaz Pleyel predominate. The apparently especially favoured La festa della pace by Franz Anton Hoffmeister also forms part of the collection, as does the first symphony of Franz Krommer. There are only two symphonies by J. Haydn, the first and third symphonies by Beethoven and none at all by Wolfgang Amadeus Mozart. The non-Austrian exceptions are a collection of six symphonies by the Venetian Angelo Baldan and the German Otto Carl Erdmann von Kospoth. Some of the preserved overtures belong to the most popular operas of the era, while others come from works that did not enjoy much success beyond the Italian peninsula. The collection also includes the Sinfonia D'un Aria della Farsa Zelinda e Lindoro by Venceslav Wratny, a composer of Czech descent active in Gorizia and Ljubljana. ${ }^{24}$

Certain parallels can be drawn between the Gorizian repertoire and that of the

${ }^{18}$ Title on source: "Sinfonia del Sig ${ }^{\mathrm{r}}$ Rampini 1775." SI-Kš, GA XI/15.

${ }^{19}$ Kokole, "Repertoar koprske stolnice," 37.

${ }^{20}$ Title on source: "Symphonie a piu stromenti." Without call number and not catalogued in RISM.

${ }^{21}$ Without title; only the oboe parts are preserved. SI-Ls, Ms. mus. 36.

${ }^{22}$ Morrow, "Symphony in the Austrian Monarchy," 414.

${ }^{23}$ Ibid., 422.

${ }^{24}$ On Wratny's church music, see Nagode, "Šest latinskih maš Venčeslava Wratnyja;” on Wratny's Sinfonia D'un Aria della Farsa Zelinda e Lindoro, see Barbo, "Referential Contexts." 
Philharmonic Society, since the latter also favoured local repertoire (by composers born and/or active within the monarchy). Moreover, works by the same composers - primarily the most prolific and popular composers of the day - are found in both collections, including some absolutely identical works: the Society also obtained symphonies by Gyrowetz and Pleyel, as well as Beethoven's first and second symphonies. Unlike the Gorizians, however, the Society acquired works by Dittersdorf and Paul Wranitzky, plus - in contrast - several Mozart symphonies. Not surprisingly, the predominant composer listed in the Society's catalogue of works drawn up in 1804 was clearly Haydn, with thirty-five symphonies. Among the composers of symphonies held by the Society, only Franz Christoph Neubauer and Louis Massoneau were non-Austrian; their works were, however, available for purchase in Vienna. Among the sinfonie concertanti, besides Gyrowetz's works, we find a number of foreign composers - François Devienne, Giuseppe Antonio Capuzzi, Carl August Cannabich and Johann Brandl - but this prominent presence is due only to the fact that this distinctive species of symphony flourished in France, Mannheim and London, whereas in the Habsburg Monarchy it had a much lower profile. The overtures are either by Austrian composers or by Italian composers whose operas had gained international success or were in some way connected with Vienna - that is, either composed there or staged there for the first time.

The Philharmonic Society became the most prominent standard-bearer of the symphonic repertoire in the Slovenian territory. It has been pointed out that this society was an "anomaly," since in the Austrian Monarchy public concerts (although these were actually only semi-public, only members being admitted) were normally organized by individuals who performed whatever pieces they had at their disposal and did not function as patrons in the more significant sense of creating and cultivating a repertoire. ${ }^{25}$ From this perspective, the Society was truly unique within the empire in its acquisition of a large collection of symphonies and active encouragement of local creativity. Its catalogue of works acquired during the period 1794-1804 also lists five symphonies by František Josef Benedikt Dusík, a Czech composer active in those parts from 1790 onwards. ${ }^{26}$

Many of the symphonies and overtures that came into the possession of the Society were donated by its members: either by musicians, such as its co-founders Carl Moos and Bernard Kogl and the violinist Wolfgang Schmitt, or by its elite membership, such as the aristocrats Baron Sigismund Zois and Count Ferdinand von Porzia. Beyond the Society there was no real market for symphonies in Ljubljana, so its symphonic repertoire had to be purchased elsewhere, one assumes mainly in Vienna.

By this time, publishing and printing businesses had become well established, so the majority of the Society's symphonies arrived in the form of printed editions, mainly issued by the leading publisher André. ${ }^{27}$ This is not surprising, since by the end of the eighteenth

${ }^{25}$ Morrow, "Symphony in the Austrian Monarchy," 417.

${ }^{26}$ See Barbo, František Josef Benedikt Dusik; Barbo, "František Josef Benedikt Dusík;" and Arbo, "Dusík, Wrattni e la ricezione." There is also a modern edition of one of Dusík's symphonies: Dusík, Simphonia grande in $G$.

${ }^{27}$ On the publisher André, see Matthäus, Johann André Musikverlag; for the period after 1800, see Constapel, Der Musikverlag Johann André. 
century André had become "the single most important music publisher in Europe." 28 Although his base was in Offenbach, André's publications were generally available throughout Europe, and almost all his editions were sold in Vienna. ${ }^{29}$ We can find some of the André editions owned by the Society in the 1799 catalogue of the Viennese music dealer Johann Traeg, and in the 1804 supplement to the same dealer's catalogue. Apart from buying from André, the Society also obtained editions from well-established printing firms based in Vienna, notably those of the prominent Artaria as well as Hoffmeister.

Despite the great expansion of music publishing, manuscript copies still circulated in abundance, and this form of distribution remained highly characteristic of the Habsburg monarchy even as late as the end of the century. ${ }^{30}$ A preference for hand-copied rather than printed symphonies is observable in certain sources obtained by the Society. Of the Haydn symphonies in the collection, three were already available from the publishing house Artaria at the time and four had been printed by firms in Paris and London, while Massoneau's Op. 3, nos. 1 and 2 had been published by André. ${ }^{31}$ The operatic sinfonias are mainly manuscript copies.

The editions in the Gorizian collection display more or less the same origins, most of them being sold by Viennese publishers and music dealers (André, Artaria and Toricella, the Viennese publishing pioneer). Nevertheless, we also find one Sieber (Paris) edition and one Schott (Mainz) edition of Pleyel's symphonies - which is interesting, since these were also published by André and would probably have been easier to obtain from him. There are also manuscript copies of Pleyel symphonies that had been published by Imbault (France) as well as a manuscript copy of Kospoth's Op. 12. The operatic sinfonias are all in manuscript form. Interestingly, some are preserved in the form of a score - which was a rare event, since such works were more normally disseminated as performance material in parts.

The printed editions preserved in Slovenian archives are generally first editions: that is, first editions from André or Viennese firms, or first Viennese editions that followed international publications by only a year or two. This proves that the Society and the Gorizian music enthusiasts were keen to acquire contemporary repertoire and made a serious effort to obtain the most recently composed symphonies. This was definitely true of the Philharmonic Society, whose catalogue citing works acquired by June 1804 includes the sinfonia to an opera that had been premiered in January 1804 as well as Beethoven's Symphony No. 2, which first became available in print that same year. ${ }^{32}$

It is interesting to observe the shift of the symphonic repertoire from international to local production that occurred at the end of the eighteenth century, when the orientation

${ }^{28}$ Jones, "Symphony in Beethoven's Vienna," 19.

${ }^{29}$ Ibid., 19-22.

${ }^{30}$ Morrow, "Symphony in the Austrian Monarchy," 423.

${ }^{31}$ Unfortunately, several symphonies by Haydn as well as works by certain other composers have not been preserved. The main source of information about the repertoire of the Philharmonic Society is their catalogue of works from 1794-1804, which contains incipits of the works owned by the Society.

${ }^{32}$ Beethoven's Symphony No. 2 is listed in the Society's catalogue, but the parts for the symphony are missing. It is most likely that the Society obtained a printed edition. 
changed in favour of Austrian composers. This transition is shown on the map below, which illustrates the origins of the symphonies preserved in Slovenian archives by mapping the cities where the respective composers lived and worked. As mentioned above, this shift was characteristic of the entire Habsburg monarchy. Given that most of the works by foreign composers were available from music dealers in Vienna, it is probably safe to conclude that this musical centre dictated absolutely what was deemed fashionable in its hinterland.

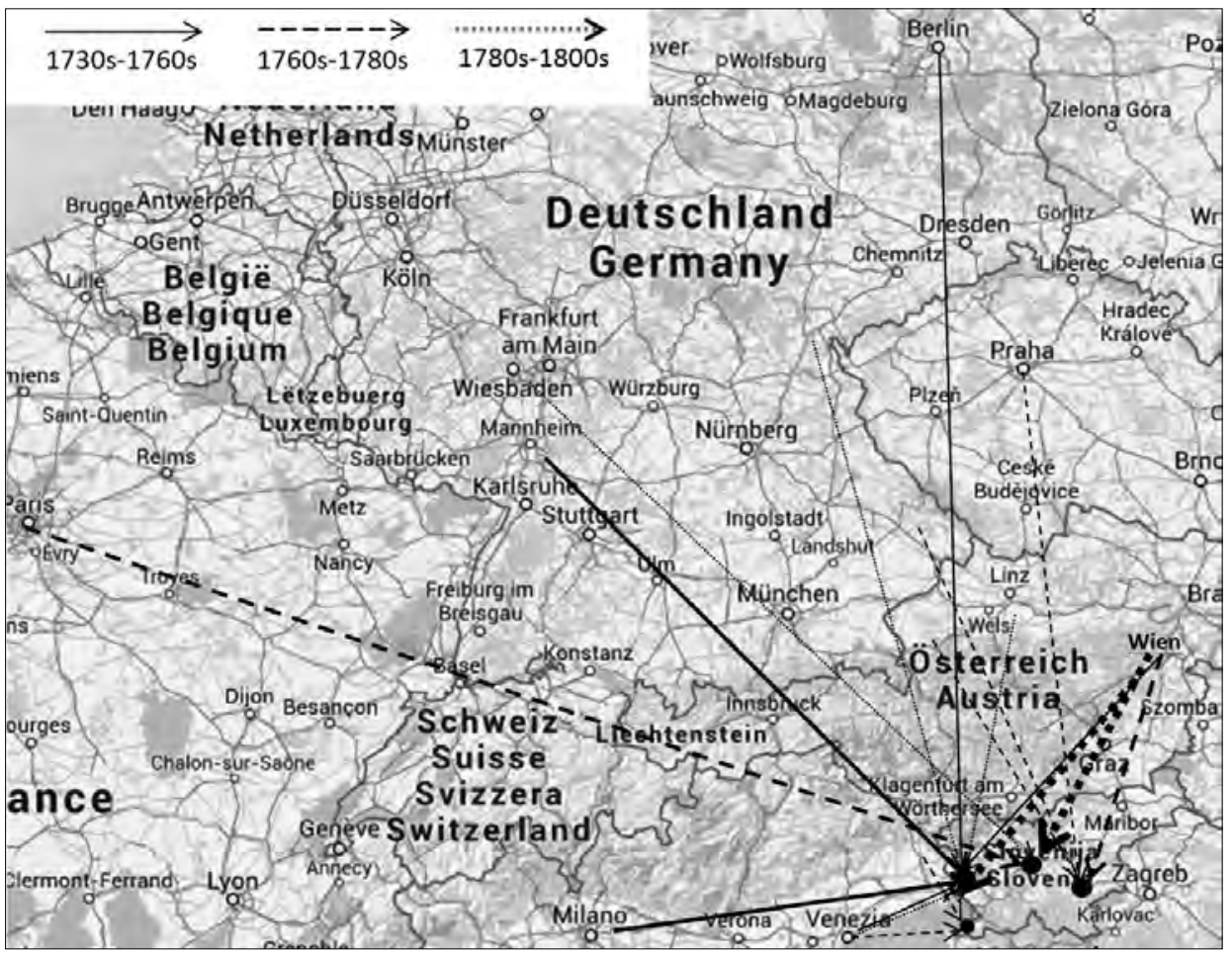

Figure 1 The shift in symphonic repertoire during the eighteenth century. Thicker lines represent a greater number of symphonies by composers from that area.

It is difficult to write about the Slovenian symphonic repertoire in the eighteenth century for two reasons. First, one can quickly be discouraged from researching into Slovenian symphonic creativity, since we do not have a Haydn or a Mozart, nor any prolific indigenous composer, leaving aside the rare exceptions of Dusík and Wratny. Second, Slovenia as such at this time did not exist, since there was not yet a self-aware Slovenian nation with a collective consciousness based on a common language, culture and economy; moreover, there were no recognized borders defining Slovenian territory. ${ }^{33}$ The vast majority of the population regarded themselves as belonging first and foremost

${ }^{33}$ Kosi, Kako je nastal, 64-65. 
to a certain duchy, and in consequence to the Habsburg monarchy. We cannot, therefore, properly speak of an expressly Slovenian symphonic repertoire and Slovenian composers; however, we may in compensation regard Austrian creativity legitimately as "local" creativity. In this light, the modern Slovenian territory was a peripheral but integral component of a large and culturally rich state. Although there were no (truly rich) patrons in this periphery capable of commissioning vast numbers of symphonies, there were at least consumers who in their more modest way contributed to the cultivation and growth of the symphonic repertoire, whereby new symphonies continued to be written so long as there was a continued demand for them. 


\section{Bibliography}

Arbo, Alessandro. "Dusík, Wrattni e la ricezione del Klassik musicale centroeuropeo a Gorizia nei primi decenni dell'Ottocento.” In Itinerari del classicismo musicale: Trieste e la Mitteleuropa, edited by Ivano Cavallini, 39-54. Lucca: Libreria Musicale Italiana (LIM), 1992.

___ I Ifondi musicali dell'Archivio storico provinciale di Gorizia. Gorizia: Provincia, 1994.

-_- Musicisti di frontiera: le attività musicali a Gorizia dal Medioevo al Novecento. Monfalcone: Edizioni della Laguna, 1998.

Barbo, Matjaž. František Josef Benedikt Dusik: The Biography of an Eighteenth-century Composer. Wien: Hollitzer Wissenschaftsverlag, 2011.

. "František Josef Benedikt Dusík and the Beginnings of Slovene Symphonic Music." Acta musicologica: Revue pro hudební vědu 5, no. 1 (2008): 1-11. http:// acta.musicologica.cz/.

____. "Referential Contexts of Early Slovenian Symphonic Music." Muzikološki zbornik 49, no. 2 (2013): 33-39.

Beck, Hermann. "Die Musik des liturgischen Gottesdienstes im 18. Jahrhundert (Messe, Offizium)," In Geschichte der katholischen Kirchenmusik, vol. 2, Vom Tridentinum bis zur Gegenwart, edited by Karl G. Fellerer, 180-189. Kassel: Bärenreiter, 1976.

Bizjak, Milko. "Frančiškani in glasba v 18. stoletju." In 500 let frančiškanov v Kamniku, edited by Emilijan Cevc, 59-63 Kamnik: Kulturni center, 1993.

Cvetko, Dragotin. Slovenska glasba v evropskem prostoru. Ljubljana: Slovenska matica, 1991.

Dusík, František Josef. Simphonia grande in G. Edited by Matjaž Barbo. Monumenta artis musicae Sloveniae 52. Ljubljana: SAZU, Muzikološki inštitut ZRC SAZU, 2007.

Faganel, Tomaž. "Glasba klasicizma v novomeških arhivih.” In 500 let Kolegiatnega kapitlja v Novem mestu, edited by Stane Granda, 215-221. Dolenjski zbornik. Novo mesto: Dolenjska založba, 1997.

"Glasbeni repertoar na Slovenskem v 18. stoletju in v prvi polovici 19. stoletja." In 300 let: Academia philharmonicorum labacensium (1701-2001), edited by Ivan Klemenčič, 119-129. Ljubljana: ZRC SAZU, 2004.

Höfler, Janez. "Glasbenozgodovinske najdbe XVII. in XIX. stoletja v Novem mestu," Kronika 15, no. 3 (1967): 135-148.

Kokole, Metoda, "Repertoar koprske stolnice v 18. stoletju.” In Glasbena dediščina slovenskih obalnih mest do 19. stoletja: vodnik po razstavi, edited by Metoda Kokole, 37-40. Ljubljana: Založba ZRC, 2003.

___ - ed. Glasbena dediščina slovenskih obalnih mest do 19. stoletja: vodnik po razstavi. Ljubljana: Založba ZRC, 2003.

. "Glasbeni utrinki s potovanja šatjerskega plemiča po Evropi 18. stoletja." Muzikološki zbornik 51, no. 1 (2015): 57-79.

- "Glasba v plemiških bivališčih na Slovenskem od srednjega veka do konca 18. stoletja.” Kronika 60, no. 3 (2012): 667-698.

. "The 1773 Production of Piccinni's La buona figliuola in Ljubljana and Other Local 
Traces of Italian Operas in the Later Part of the 18th Century." In Niccolò Piccinni: Musicista europeo, edited by Alessandro di Profio and Mariagrazia Melucci, 253-263. Bari: Adda editore, 2004.

Kosi, Jernej. Kako je nastal slovenski narod: začetki slovenskega nacionalnega gibanja v prvi polovici 19. stoletja. Ljubljana: Sophia, 2013.

Matthäus, Wolfgang. Johann André Musikverlag zu Offenbach am Main: Verlagsgeschichte und Bibliographie 1772-1800. Tutzing: Hans Schneider, 1973.

Morrow, Mary Sue, and Bathia Churgin, eds. The Symphonic Repertoire. Vol. 1, The Eighteenth-Century Symphony. Bloomington: Indiana University Press, 2012.

___ " "Patrons and Practices." In The Symphonic Repertoire, vol. 1, The EighteenthCentury Symphony, edited by Mary Sue Morrow and Bathia Churgin, 75-99. Bloomington: Indiana University Press, 2012.

___ _ "The Symphony in the Austrian Monarchy." In The Symphonic Repertoire, vol. 1, The Eighteenth-Century Symphony, edited by Mary Sue Morrow and Bathia Churgin, 411-471. Bloomington: Indiana University Press, 2012.

Nagode, Aleš. “Šest latinskih maš Venčeslava Wratnyja.” Master's thesis, Univerza v Ljubljani, 1994.

Škrjanc, Radovan. "Frančiškanske korne knjige v Novem mestu iz 18. stoletja." De musica disserenda 10, no. 2 (2014): 65-86.

___ _ "O času in kraju nastanka ter avtorstvu novomeškega rokopisa Noten-Buch vorinnen die Fundamenta zu dem Clavier oder Orgel enthalten.” De musica disserenda 7 , no. 1 (2011): 85-112.

___ . "Prispevek k poznavanju repertoarja starejših muzikalij cerkvene glasbe v Sloveniji." Pts. 1 and 2. De musica disserenda 1, nos. 1-2 (2005): 141-165; 2, no. 1 (2006): 31-60.

. "Relativnost in funkcija zgodovinopisnega interpretiranja glasbe: predstavitev problema na primeru zgodovinske analize novomeških Fundamenta." Muzikološki zbornik 47, no. 1 (2011): 75-91.

Riedel, Friedrich Wilhelm. "Die Bedeutung der Musikpflege in den österreichischen Stiften zur Zeit von Joseph und Michael Haydn.” Kirchenmusikalisches Jahrbuch 71 (1987): 55-63.

."Joseph Haydns Sinfonien als liturgische Musik," In Festschrift Hubert Unverricht zum 65. Geburtstag, edited by Karl-Heinz Schlager, 213-220. Tutzing: Hans Schneider, 1992.

Venišnik, Vesna. "Instrumental Music and Franciscan Liturgy.” Muzikološki zbornik 50, no. 2 (2014): 93-99.

___ . "Simfonični repertoar Goriške dežele v 18. in zgodnjem 19. stoletju." De musica disserenda 10, no. 2 (2014): 57-64.

Wyn Jones, David. The Symphony in Beethoven's Vienna. Cambridge: Cambridge University Press, 2011.

Zaslaw, Neal. "Mozart, Haydn and the Sinfonia da Chiesa." The Journal of Musicology 1 (1982): 95-124. 


\section{IZVOR ZGODNJEGA SIMFONIČNEGA REPERTOARJA NA SLOVENSKEM}

\section{Povzetek}

Ohranjeni rokopisi in tiski simfoničnih del v arhivih na Slovenskem in v obmejnem mestu Gorici dokazujejo, da so skozi 18. stoletje v slovenskih deželah ljubitelji glasbe sledili trendu naraščajoče priljubljenosti simfonije in uspeli pridobiti najnovejša simfonična dela. V Zgodovinskem arhivu v Gorici se je ohranilo precej simfonij, ki izhajajo iz obdobja od tridesetih let 18. stoletja do začetka 19. stoletja. V zbirki najdemo primere zgodnje simfonične ustvarjalnosti najbolj razširjenih evropskih skladateljev: mannheimski skladatelji I. Holzbauer, J. Stamitz in C. G. Toeschi, skladatelja milanskega kroga G. B. Sammartini in A. Brioschi, dela G. C. Wagenseila, edinega avstrijskega skladatelja svoje generacije, ki je uspel pridobiti mednarodni sloves, ter simfoniji J. C. Bacha in J. G. Seyffartha. Naštete simfonije so nastale v obdobju od okoli 1730 do okoli 1760 in so ohranjene v obliki prepisov. Na kakšen način in od kod so simfonije prišle, ni mogoče natančneje določiti. Velika večina simfonij iz tega obdobja je spetih v več zvezkov, v katerih je še precej del drugih žanrov, ki so dela italijanskih skladateljev. Slednje nakazuje, da je tudi simfonični repertoar prihajal najverjetneje preko italijanske strani.

$\mathrm{K}$ razvoju in distribuciji simfonij so precej pripomogle cerkvene ustanove, kar potrjujejo ohranjeni primeri v frančiškanski knjižnici v Novem mestu, arhivih nekaterih primorskih samostanov ter ohranjene muzikalije stolne cerkve v Ljubljani. Te simfonije so nastale v obdobju med letoma 1750 in 1780 . Samostani so med seboj tvorili posebno povezavo, preko katere se je širil simfonični repertoar. Slednje je razvidno tudi iz primerov muzikalij v frančiškanskem samostanu: simfonijo češkega skladatelja Antonína Kammela je s seboj najverjetneje prinesel pater Mauricij Pöhm, ko se je nastanil v novomeškem frančiškanskem samostanu, iz medsebojne samostanske povezave izhaja tudi zbirka simfonij patra Lamberta Krausa iz benediktinskega samostana Metten, ki jo najdemo skoraj izključno v samostanskih zbirkah.

Ob koncu stoletja so simfonični repertoar v Habsburški monarhiji sestavljala skoraj izključno dela lokalnih avstrijskih skladateljev oz. skladateljev, delujočih na Dunaju. Slednje je bilo značilno tudi za leta 1794 ustanovljeno Filharmonično družbo in za simfonije iz Zgodovinskega arhiva v Gorici, ki datirajo v konec 18. stoletja. V obeh zbirkah najdemo dela najbolj priljubljenih skladateljev dobe A. Gyrowertza, I. Pleyela, J. Haydna in zgodnje simfonije L. Beethovna. Filharmonična družba je vključila v svojo bogato zakladnico del tudi simfonije C. D. Dittersdorfa, P. Wranitzkega in seveda W. A. Mozarta. V obeh zbirkah so primeri simfonij tujih skladateljev redki. Simfonije iz tega časa so načeloma tiskane edicije uveljavljenih firm na Dunaju (Artaria, Toricella, Hoffmeister) in pa seveda najpomembnejše glasbene založniške firme Andréja iz Offenbacha, katerega edicije je bilo mogoče kupiti na Dunaju. Kljub temu je nekaj simfonij Haydna in Pleyela, ki so že obstajale v tiskanih oblikah, ohranjenih v obliki prepisov. V Habsburški monarhiji je namreč kljub uveljavitvi glasbenega tiska prevladovalo prepisovanje simfonij.

Tiskane izdaje so načeloma vse prve edicije simfonij; gre za prve edicije dunajskih firm in založnika Andréja ali za prve dunajske edicije, ki so po letu ali dveh sledile izdajam v Parizu ali Londonu. Filharmonična družba in goriški ljubitelji glasbe so tako 
pridobivali sodoben repertoar in zagotovo stremeli $\mathrm{k}$ temu, da bi pridobili najnovejše simfonije, ki so bile na voljo.

Slovensko ozemlje je bilo v 18. stoletju periferija velike in kulturno bogate države. Sicer drži, da tukajšnji prostor ni premogel bogatih mecenov, ki bi za svoje potrebe lahko naročali številne nove simfonije, zaradi česar je ohranjenih (oz. je nastalo) le nekaj simfonij tukaj živečih skladateljev. Vendarle pa so Filharmonična družba, goriške aristokratske družine in cerkvene institucije simfonije potrebovali in so z njihovim nakupom posredno spodbujali tudi nastanek novih del. 